\title{
Evaluation of organophosphorus and synthetic pyrethroid insecticides against six vector mosquitoe species
}

\author{
Domingo Montada Dorta*, V. Vasuki**, A. Rajavel**
}

\begin{abstract}
DORTA, D.M. et al. Evaluation of organophosphorus and synthetic pyrethroid insecticides against six vector mosquitoe species. Rev. Saúde Pública, 27: 391-7, 1993. Three organophosphorus compounds- malathion, folithion and temephos- and two synthetic pyrethroids- alphamethrin and deltamethrin- were used for monitoring the susceptibility status of larvae and adults of six vector mosquitoe species: Culex quinquefasciatus (Filariasis) and Aedes albopictus (Dengue) (both laboratory and field strains); laboratory strains of Aedes aegypti (Dengue), Anopheles stephensi and Anopheles culicifacies (Malaria), and Culex tritaeniorhynchus (Japanese encephalitis) in India. From the $\mathrm{LC}_{50}$ values obtained for these insecticides, it was found that all mosquito species including the field strains of $C x$. quinquefasciatus and Ae. albopictus were highly susceptible Except for $C x$. quinquefasciatus (field strain) against malathion, $100 \%$ mortality was observed at the discriminating dosages recommended by World Health Organization. The residual effect of alphamethrin, deltamethrin, malathion and folithion at $25 \mathrm{mg}(\mathrm{ai}) / \mathrm{m}^{2}$ on different surfaces against six species of vector mosquitoes showed that alphamethrin was the most effective on all four treated surfaces (mud, plywood, cement and thatch). Nevertheless, residual efficacy lasted longer on thatch than on the other surfaces. Therefore, synthetic pyrethroids such as alphamethrin can be effectively employed in integrated vector control operations.
\end{abstract}

Key words: Mosquito control, methods. Insecticides, toxicity. Insect vectors.

\section{Introduction}

The use of chemicals to control insects possibly dates back to classical Greece and Rome. In the twentieth century, after the insecticidal potential of DDT was discovered and insecticidal organophosphorous compounds were developed, a new era of insect and pest control began (Hassall ${ }^{14}$, 1982). Unfortunately problems relating to the use of insecticides have arisen, some of them serious and causing considerable concern in scientific as well as in lay circles (Beroza $\left.{ }^{4}, 1970\right)$. The development of resistance in mosquitoes to a wide variety of conventional insecticides has posed a serious problem for vector control program (Georghiou et al. ${ }^{1213}$, 1966; 1973; Das and Rajagopalan $^{8}$, 1980; Ariaratnan and Georghiou ${ }^{3}$, 1975). To overcome these problems, the search for new compounds with insecticidal effect has been undertaken throughout the world. A new group of

\footnotetext{
* Instituto de Medicina Tropical Pedro Kouri - Lisa Habana - Cuba

* Vector Control Research Centre (WHO Collaborating Centre for Research and Training in Integrated Methods of Vector Control Pondicherry - India)
}

Reprints: D.M. Dorta - Autopista Novia del Mediodia $\mathrm{km} 6$ e/ Autopista Nacional y Carretera Central - Apartado 601 Lisa Habana - Cuba compounds known as synthetic pyrethroids, less toxic and comparatively safer, are promising tools for future vector control program (Elliot et al ${ }^{11}$, 1978; Darwazeh et al. ${ }^{6}, 1978$; Poister et al. ${ }^{18}$, 1981; Kottkump et al. ${ }^{16}, 1981$ ).

The present study compares the susceptibility status of larvae and adults of six vector mosquito species viz. Culex quinquefasciatus (Filariasis), Anopheles stephensi and Anopheles culicifacies (Malaria), Aedes aegypti and Aeds albopictus (Dengue) and Culex tritaeniorhynchus (Japanese encephalitis) in India (Manson-Bahr and Bell17, 1982) to three organophosphorus compounds and two synthetic pyrethroids, using both laboratory and field strains of mosquito.

\section{Material and Method}

Malathion (50\% EC), folithion (50\% EC), temephos ( $50 \% \mathrm{EC})$, deltamethrin (Technical grade 99.9\%) and alphamethrin (10\% EC) were used for monitoring the susceptibility status of adults and larvae of $C x$. quinquefasciatus, An. stephensi, Ae. aegypti, Ae. albopictus, An. culicifacies and $C x$. tritaeniorhynchus, maintained at the insectories, Vector Control Research Centre, Pondicherry. In the cases of $C x$. quinquefasciatus and Ae. albopictus field collected strains were also used. Insecticide impregnated papers for monitoring the adult 
susceptibility (Busvine ${ }^{5}, 1958$ ) and standard solutions for assessing the larval susceptibility (WHO ${ }^{23}, 1981$ ) were prepared in different concentrations at the VCRC. The procedures followed for determining the susceptibility status of larva and adult are the same as described by $\mathrm{WHO}^{23,24}$, 1981). From the percentage mortalities resulting from different concentrations, $\mathrm{LC}_{50}$ and $\mathrm{LC}_{90}$ values were obtained by probit analysis (Sokal and Rohlf $^{21}, 1981$ ). Control mortality, if any, was corrected by using Abbott's formula (Abbott ${ }^{1}, 1925$ ).

To evaluate residual activity, a bioassay was carried out in accordance with WHO methodology (WHO25, 1981), modificd at VCRC (Rajavel et al $\left.{ }^{19}, 1987\right)$. Malathion (5\% WP), alphamethrin (5\% WP), deltamuthrin (2.5\% WP) and folithion ( $50 \%$ EC) were sprayed at the rate of $25 \mathrm{mg}$ (ai)/ $\mathrm{m}^{2}$ on different surfaces viz. cement, mud, thatch and plywood. The mosquito were exposed to treated surfaces for 1 hour and after 24 hours mortality was recorded at weekly intervals until
$50 \%$ mortality was observed. All the experiments were carried out at $27 \pm 2^{\circ} \mathrm{C}$ and $70-80 \%$ relative humidity.

\section{Results and Discussion}

Larvicidal efficacy of deltamethrin, alphamethrin, temephos and folithion against six species of mosquito is shown in tables 1-4. The $\mathrm{LC}_{50}$ values given in Table 1 showed that deltamethrin was more effective against $C x$. quinquefasciatus (lab) than the other mosquito species tested. An. stcphensi was found to be the least susceptible. The ficld strain of $C x$. quinquefasciatus was found to bc about 260 times less susceptible than the laboratory strain, when tested under similar condictions, using decamethrin against $C x$. quinquefasciatus (lab.) and Ae. acgypti, it was found to be 24 and 12 times less susceptible respectively than the same strains tested on this occasion. On the other

Table 1. Larval susceptibility status of six vector mosquitoes to deltamethrin.

\begin{tabular}{|c|c|c|c|c|c|}
\hline Species & $\begin{array}{l}\mathrm{LC}_{50} \\
(\mathrm{mg} / 1)\end{array}$ & $\begin{array}{l}L_{C_{90}} \\
(m g / 1)\end{array}$ & $\begin{array}{l}\text { Regression equation } \\
(Y=a+b \ln X)\end{array}$ & $x^{2}$ & $\begin{array}{l}95 \% \text { Fiducial limits } \\
\text { LCL - UCL }\end{array}$ \\
\hline \multicolumn{6}{|c|}{ Laboratory strain } \\
\hline $\begin{array}{l}\text { Cx. quinquefasciatus } \\
\text { Cx. tritaeniorhynchus } \\
\text { An. culicifacies } \\
\text { An. stephensi } \\
\text { Ae. aegypti } \\
\text { Ae. albopictus }\end{array}$ & $\begin{array}{l}2.95 \times 10^{-6} \\
1.32 \times 10^{-5} \\
2.14 \times 10^{-5} \\
5.25 \times 10^{-3} \\
8.20 \times 10^{-6} \\
4.57 \times 10^{-6}\end{array}$ & $\begin{array}{l}7.45 \times 10^{-5} \\
8.73 \times 10^{-5} \\
2.62 \times 10^{-4} \\
1.08 \times 10^{-2} \\
7.17 \times 10^{-5} \\
6.49 \times 10^{.5}\end{array}$ & $\begin{array}{l}Y=10.04+0.39 \ln X \\
Y=12.62+0.68 \ln X \\
Y=10.49+0.51 \ln X \\
Y=14.29+1.77 \ln X \\
Y=11.92+0.59 \ln X \\
Y=10.93+0.48 \ln X\end{array}$ & $\begin{array}{r}2.39 \\
0.19 \\
0.41 \\
7.56^{*} \\
10.77^{*} \\
7.51^{*}\end{array}$ & $\begin{array}{l}4.12 \times 10^{-5}-1.40 \times 10^{0.4} \\
6.36 \times 10^{0.5}-1.20 \times 10^{-4} \\
1.69 \times 10^{-4}-4.07 \times 10^{-4} \\
9.54 \times 10^{-3}-1.23 \times 10^{0.2} \\
5.27 \times 10^{-5}-9.76 \times 10^{0.5} \\
4.20 \times 10^{-5}-1.00 \times 10^{-4}\end{array}$ \\
\hline \multicolumn{6}{|c|}{ Field strain } \\
\hline $\begin{array}{l}\text { Cx. quinquefasciatus } \\
\text { Ae. albopictus }\end{array}$ & $\begin{array}{l}7.77 \times 10^{.4} \\
9.69 \times 10^{.6}\end{array}$ & $\begin{array}{l}1.07 \times 10^{-3} \\
6.41 \times 10^{.5}\end{array}$ & $\begin{array}{l}Y=33.55+3.99 \ln X \\
Y=12.82+0.68 \ln X\end{array}$ & $\begin{array}{l}0.28 \\
4.57\end{array}$ & $\begin{array}{l}1.69 \times 10^{-4}-1.17 \times 10^{-4} \\
4.43 \times 10^{-5}-9.28 \times 10^{-5}\end{array}$ \\
\hline
\end{tabular}

- Heterogeneity.

Table 2. Larval susceptibility status of six vector mosquitoes to alphamethrin.

\begin{tabular}{|c|c|c|c|c|c|}
\hline Species & $\begin{array}{l}\mathrm{LC}_{50} \\
(\mathrm{mg} / 1)\end{array}$ & $\begin{array}{l}\mathrm{LC}_{90} \\
(\mathrm{mg} / 1)\end{array}$ & $\begin{array}{l}\text { Regression equation } \\
(Y=a+b \ln X)\end{array}$ & $x^{2}$ & $\begin{array}{l}\text { 95\% Fiducial limits } \\
\mathrm{LCL} \quad-\quad \text { UCL }\end{array}$ \\
\hline \multicolumn{6}{|c|}{ Laboratory strain } \\
\hline $\begin{array}{l}\text { Cx. quinquefasciatus } \\
\text { Cx. tritaeniorhynchus } \\
\text { An. culicifacies } \\
\text { An. stephensi } \\
\text { Ae. aegypti } \\
\text { Ae. albopictus }\end{array}$ & $\begin{array}{l}2.29 \times 10^{-7} \\
2.02 \times 10^{-7} \\
1.07 \times 10^{-6} \\
1.03 \times 10^{-4} \\
1.81 \times 10^{-7} \\
3.31 \times 10^{-7}\end{array}$ & $\begin{array}{l}6.58 \times 10^{.7} \\
5.86 \times 10^{-7} \\
9.85 \times 10^{-6} \\
8.89 \times 10^{-4} \\
3.72 \times 10^{-6} \\
1.08 \times 10^{-6}\end{array}$ & $\begin{array}{l}Y=23.52+1.21 \ln X \\
Y=23.55+1.20 \ln X \\
Y=12.94+0.58 \ln X \\
Y=10.45+0.59 \ln X \\
Y=14.40+0.65 \ln X \\
Y=22.30+1.17 \ln X\end{array}$ & $\begin{array}{r}3.21 \\
2.78 \\
10.02 \\
5.00 \\
4.96 \\
2.31\end{array}$ & $\begin{array}{l}5.39 \times 10^{-7}-8.03 \times 10^{-7} \\
4.62 \times 10^{-7}-7.43 \times 10^{-7} \\
6.55 \times 10^{-6}-1.48 \times 10^{-5} \\
5.38 \times 10^{-4}-1.47 \times 10^{-3} \\
2.48 \times 10^{-6}-5.58 \times 10^{-6} \\
8.80 \times 10^{-7}=1.33 \times 10^{-6}\end{array}$ \\
\hline \multicolumn{6}{|c|}{ Field strain } \\
\hline $\begin{array}{l}\text { Cx. quinquefasciatus } \\
A \theta . \text { albopictus }\end{array}$ & $\begin{array}{l}1.34 \times 10^{0.4} \\
3.69 \times 10^{.7}\end{array}$ & $\begin{array}{l}4.99 \times 10^{-4} \\
1.10 \times 10^{0.6}\end{array}$ & $\begin{array}{l}Y=13.60+0.97 \ln X \\
Y=22.35+1.17 \ln X\end{array}$ & $\begin{array}{l}0.90 \\
1.85\end{array}$ & $\begin{array}{l}3.80 \times 10^{-4}-6.57 \times 10^{-4} \\
8.52 \times 10^{-7}-1.42 \times 10^{-6}\end{array}$ \\
\hline
\end{tabular}

- Heterogeneity. 
hand, Cx. quinquefasciatus (field) and An. stephensi where found to be twice as susceptible as had bcen reported earlicr for the same insecticide (Das and Kalyanasundaram ${ }^{10}$, 1984).

Larval $\mathrm{LC}_{50}$ and $\mathrm{LC}_{90}$ valucs of alphamethrin are presented in Table 2 and the results indicate that $A e$. aegypti was the most and $C x$. quinquefasciatus (field) the lcast susceptible species. In an earlicr study when alphamethrin was tested against $C x$. quinquefasciatus, Ae, aegypti and $A n$. stephensi (Amalraj et al. ${ }^{2}, 1987$ ) it showed a potency 600,83 and 40 times higher respectively than that here observed.

In comparison, $C x$. quinquefasciatus (field), $C x$. tritaeniorhynchus, An. culicifacies, Cx. quinquefasciatus (lab), An. stephensi, Ae. albopictus (lab.), Ae. aegypti and $A$ e. albopictus (field) were respectively $6,66,100,13,52,13,52,13,45$ and 27 times less susceptible to deltamethrin than to alphamethrin.

Larval $\mathrm{LC}_{50}$ and $\mathrm{LC}_{90}$ values presented in Table 3 reveal that Ae. albopictus from laboratory was the most susceptible, and An. stephensi the least susceptible species to temephos. The susceptibility status of $C x$. quinquefasciatus, An. stephensi, Ae. aegypti and An. culicifacies observed in the presented study was $88,40,30$ and 550 times higher respectively than that reported earlier for the Pondicherry strains of the same species (Das and Rajagopalan ${ }^{7}, 1979$; Das et al. ${ }^{9}, 1980$ ).

The explanation might be that the strains used in the present study are from a laboratory colonies which have been maintained for about 14 years. It is therefore likely that even if the natural population were resistant, this phenomenon night have been reversed in the laboratory colony due to the removal of selection pressure.

Susceptibility status was determined for larvae of the same mosquito to folithion (fenitrothion). The values showed that $C x$. tritaeniorhynchu and Ae. albopictus (field \& lab.) were more susceptible than the other species tested. American strains of Ae. albopictus were also reported to be suscep-

Table 3. Larval susceptibility status of six vector mosquitoes to temephos.

\begin{tabular}{|c|c|c|c|c|c|}
\hline Species & $\begin{array}{l}\mathrm{LC}_{50} \\
(\mathrm{mg} / 1)\end{array}$ & $\begin{array}{l}\mathrm{LC}_{90} \\
(\mathrm{mg} / 1)\end{array}$ & $\begin{array}{l}\text { Regression equation } \\
\qquad(Y=a+b 1 n X)\end{array}$ & $x^{2}$ & $\begin{array}{l}95 \% \text { Fiducial limits } \\
\mathrm{LCL} \quad-\quad \text { UCL }\end{array}$ \\
\hline \multicolumn{6}{|c|}{ Laboratory strain } \\
\hline $\begin{array}{l}\text { Cx. quinquefasciatus } \\
\text { Cx. tritaeniorhynchus } \\
\text { An. culicifacies } \\
\text { An. stephensi } \\
\text { Ae. aegypti } \\
\text { Ae. albopictus }\end{array}$ & $\begin{array}{l}9.10 \times 10^{-5} \\
1.20 \times 10^{-6} \\
3.44 \times 10^{-6} \\
1.37 \times 10^{-3} \\
1.36 \times 10^{-4} \\
6.81 \times 10^{-7}\end{array}$ & $\begin{array}{l}1.03 \times 10^{-4} \\
5.30 \times 10^{-6} \\
9.17 \times 10^{-6} \\
2.01 \times 10^{-3} \\
2.96 \times 10^{-4} \\
5.66 \times 10^{-6}\end{array}$ & $\begin{array}{l}Y=99.25+10.12 \ln X \\
Y=14.76+0.86 \ln X \\
Y=21.45+1.31 \ln X \\
Y=26.82+3.31 \ln X \\
Y=19.65+1.65 \ln X \\
Y=13.58+0.60 \ln X\end{array}$ & $\begin{array}{c}16.46^{*} \\
3.66 \\
6.83^{*} \\
13.00^{*} \\
2.69 \\
3.30\end{array}$ & $\begin{array}{l}1.00 \times 10^{-4}-1.05 \times 10^{-4} \\
3.79 \times 10^{-6}-7.40 \times 10^{-6} \\
7.48 \times 10^{-6}-1.12 \times 10^{-6} \\
1.87 \times 10^{-3}-2.16 \times 10^{-3} \\
2.36 \times 10^{-4}-3.70 \times 10^{-4} \\
4.09 \times 10^{-6}-7.83 \times 10^{-6}\end{array}$ \\
\hline \multicolumn{6}{|c|}{ Field strain } \\
\hline $\begin{array}{l}\text { Cx. quinquefasciatus } \\
\text { Ae. albopictus }\end{array}$ & $\begin{array}{l}4.73 \times 10^{-5} \\
1.57 \times 10^{-6}\end{array}$ & $\begin{array}{l}4.11 \times 10^{-4} \\
1.11 \times 10^{0.5}\end{array}$ & $\begin{array}{l}Y=28.05+2.40 \ln X \\
Y=13.74+0.65 \ln X\end{array}$ & $\begin{array}{l}0.27 \\
0.95\end{array}$ & $\begin{array}{l}1.02 \times 10^{-4}-1.29 \times 10^{-4} \\
7.22 \times 10^{-6}-1.71 \times 10^{-5}\end{array}$ \\
\hline
\end{tabular}

- Heterogeneity.

Table 4. Larval susceptibility status of six vector mosquitoes to folithion.

\begin{tabular}{|c|c|c|c|c|c|}
\hline Species & $\begin{array}{l}\mathrm{LC}_{50} \\
(\mathrm{mg} / 1)\end{array}$ & $\begin{array}{l}L_{C_{90}} \\
\left(m g^{\prime} / 1\right)\end{array}$ & $\begin{array}{l}\text { Regression equation } \\
\qquad(Y=a+b \ln X)\end{array}$ & $\mathrm{x}^{2}$ & $\begin{array}{l}\text { 95\% Fiducial limits } \\
\text { LCL - UCL }\end{array}$ \\
\hline \multicolumn{6}{|c|}{ Laboratory strain } \\
\hline $\begin{array}{l}\text { Cx. quinquefasciatus } \\
\text { Cx. tritaeniorhynchus } \\
\text { An. culicifacies } \\
\text { An. stephensi } \\
\text { Ae. aegypti } \\
\text { Ae. albopictus }\end{array}$ & $\begin{array}{l}4.30 \times 10^{-3} \\
2.25 \times 10^{-5} \\
1.42 \times 10^{-3} \\
7.08 \times 10^{-2} \\
2.57 \times 10^{-3} \\
2.38 \times 10^{-5}\end{array}$ & $\begin{array}{l}6.93 \times 10^{-3} \\
9.09 \times 10^{-5} \\
4.18 \times 10^{-2} \\
9.54 \times 10^{-2} \\
4.37 \times 10^{.3} \\
1.00 \times 10^{-4}\end{array}$ & $\begin{array}{l}Y=19.58+2.68 \ln X \\
Y=14.82+0.92 \ln X \\
Y=7.48+0.38 \ln X \\
Y=16.35+4.28 \ln X \\
Y=19.41+2.42 \ln X \\
Y=14.46+0.89 \ln X\end{array}$ & $\begin{array}{l}0.15 \\
0.35 \\
0.11 \\
0.15 \\
0.56 \\
0.80\end{array}$ & $\begin{array}{l}6.32 \times 10^{-3}-7.60 \times 10^{-3} \\
7.23 \times 10^{-5}-1.14 \times 10^{-4} \\
2.39 \times 10^{-2}-7.28 \times 10^{-2} \\
6.32 \times 10^{-2}-7.60 \times 10^{-1} \\
4.03 \times 10^{-3}-4.75 \times 10^{-3} \\
7.90 \times 10^{-5}-1.28 \times 10^{-4}\end{array}$ \\
\hline \multicolumn{6}{|c|}{ Field strain } \\
\hline $\begin{array}{l}\text { Cx. quinquefasciatus } \\
\text { Ae. albopictus }\end{array}$ & $\begin{array}{l}7.58 \times 10^{-3} \\
2.23 \times 10^{-5}\end{array}$ & $\begin{array}{l}1.07 \times 10^{-2} \\
1.77 \times 10^{-4}\end{array}$ & $\begin{array}{l}Y=22.92+3.67 \ln X \\
Y=11.61+0.62 \ln X\end{array}$ & $\begin{array}{l}0.80 \\
0.003\end{array}$ & $\begin{array}{l}1.06 \times 10^{-2}-1.14 \times 10^{-2} \\
1.11 \times 10^{-4}-2.83 \times 10^{-4}\end{array}$ \\
\hline
\end{tabular}

- Heterogeneity. 
tible to malathion. Conversely to this, Ae. albopictus resistant to folithion has been reported in Japan and the USA (Wesson'22, 1990). In the present study An. stephensi was found to be least susceptible to deltamethrin, temephos and folithion. Another interesting observation relates to the fact that $\mathrm{LC}_{50}$ values determined in the current study are considerable lower than the discriminating dosages recommended by WHO for the insecticides tested. This strongly suggests the need for determining the discriminating dose for different vector species from different areas, so that some base line data are made available for monitoring the resistance/susceptibility status of the vector mosquitoes in the field. Development of resistance cannot be detected early, if the high discriminating dosages recommended by the WHO are used.

When adults were exposed to the diagnostic doses of malathion, folithion, alphamethrin and deltamethrin recommended by WHO $\left(1981^{24}\right)$, a $100 \%$ mortality was observed in all species except $C x$. quinquefasciatus from field to malathion (52.5\%). However, adults of Ae. albopictus were highly susceptible to malathion with $\mathrm{LT}_{50}$ value of $6.65 \mathrm{~min}$ (Chi sq. 0.594). Earlicr studies had showed that $C x$. quinquefasciatus adults collected in the field from Pondicherry were highly suscepti- ble to malathion (Das et al. $.^{9}, 1980$ ). The present study has shown that $C x$. quinquefasciatus has a potentiality to develop resistance to this O.P. compound. Malathion resistance in the adults of $\mathrm{Ae}$. albopictus adults has been observed in Sri Lanka and Texas (Robert and Olson ${ }^{20}, 1990 ;$ WHO $^{26}, 1986$ ).

The residual effect of deltamethrin, alphamethrin, malathion and folithion at $25 \mathrm{mg}(\mathrm{ai}) / \mathrm{m}^{2}$ on different surfaces against six species of vector mosquitoes is presented in Fig. 1-4. In general both pyrethroid compounds, deltamethrin and alphamethrin were more effective than malathion and folithion.

As between the two synthetic pyrethroids tested, alphamethrin show the highest residual activity on all surfaces against all the mosquito species tested, in accordance with the results reported earlier (Amalraj et $\mathrm{al}^{2}$, 1987). However, the bioassay conducted on mud, cement, thatch and plywood showed that the residual efficacy of deltamethrin and alphamethrin lasted longer (8-17 wks) on the thatched surface than on the other three surfaces. Earlier reports showed that the residual efficacy of alphamethrin tested on the same surfaces at 100 $\mathrm{mg}\left(\right.$ ai) $/ \mathrm{m}^{2}$ lasted for 20 wks against $C x$. quinquefasciatus and An. stephensi, but it was more effective on the cement surface (Almaraj et al. ${ }^{2}, 1987$ ).

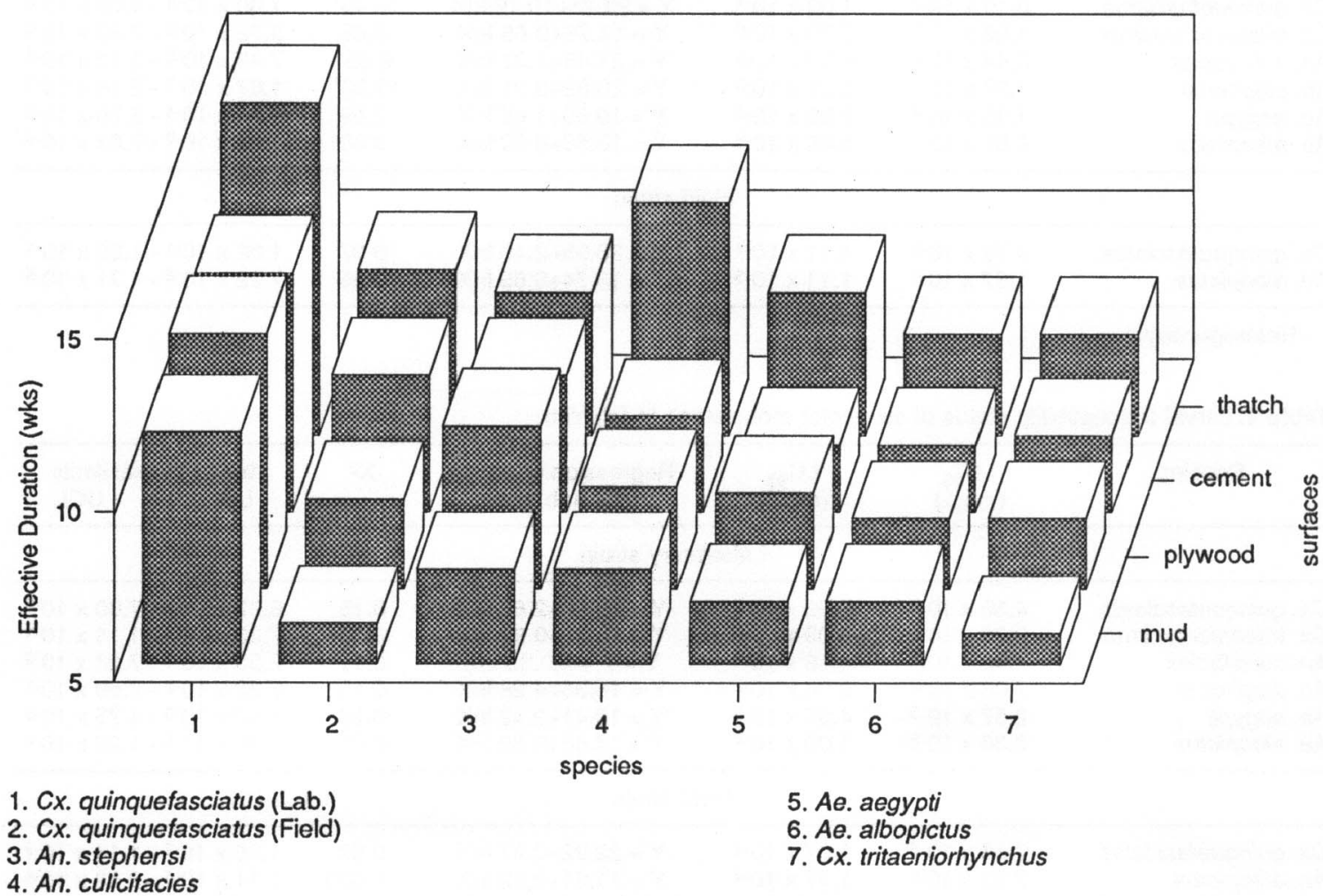

Figure 1. Residual efficacy of Deltamethrin. 


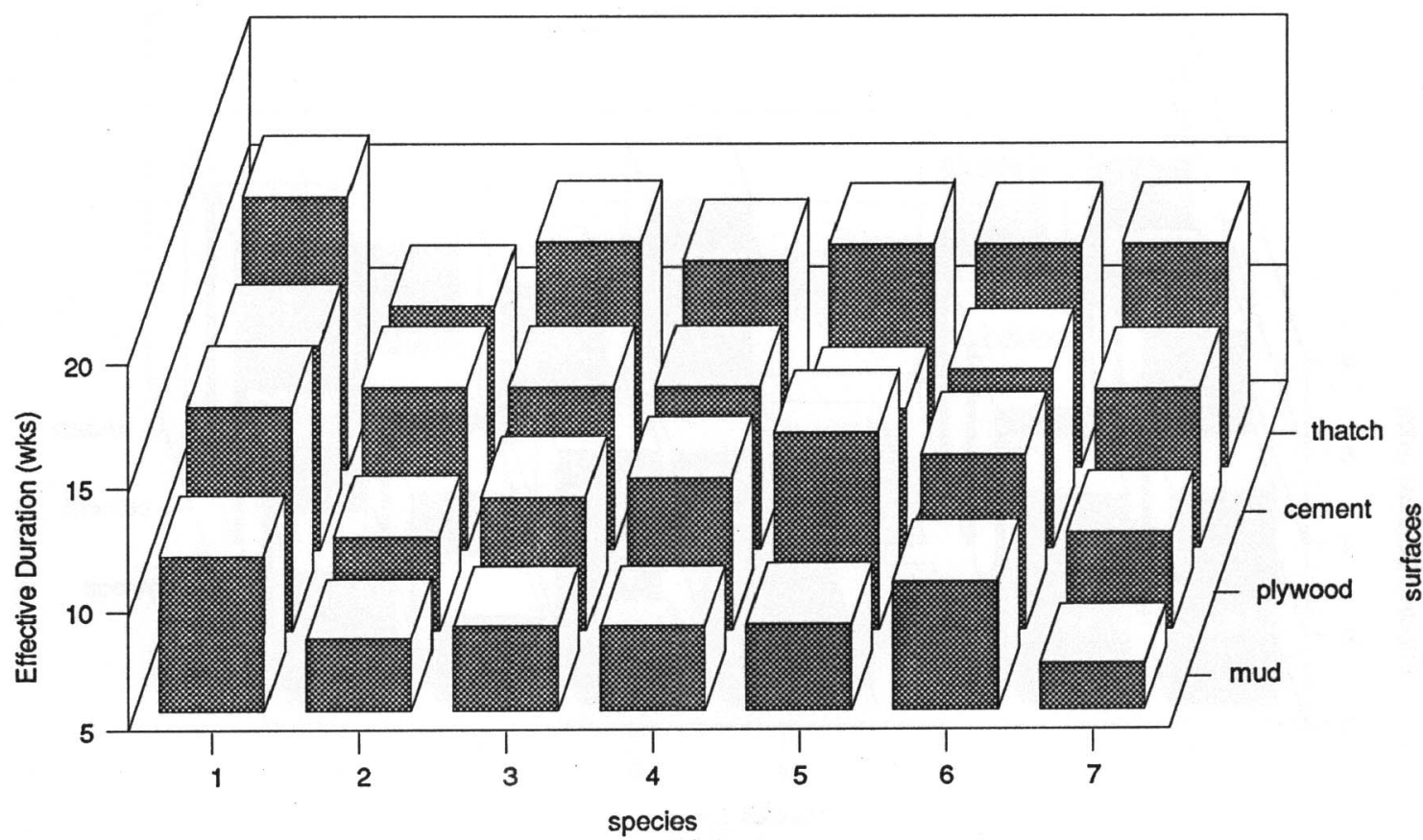
1. Cx. quinquefasciatus (Lab.)
2. Cx. quinquefasciatus (Field)
3. An. stephensi

5. Ae. aegypti

6. Ae. albopictus

7. Cx. tritaeniorhynchus

4. An. culicifacies

Figure 2. Residual efficacy of Alphametrin.

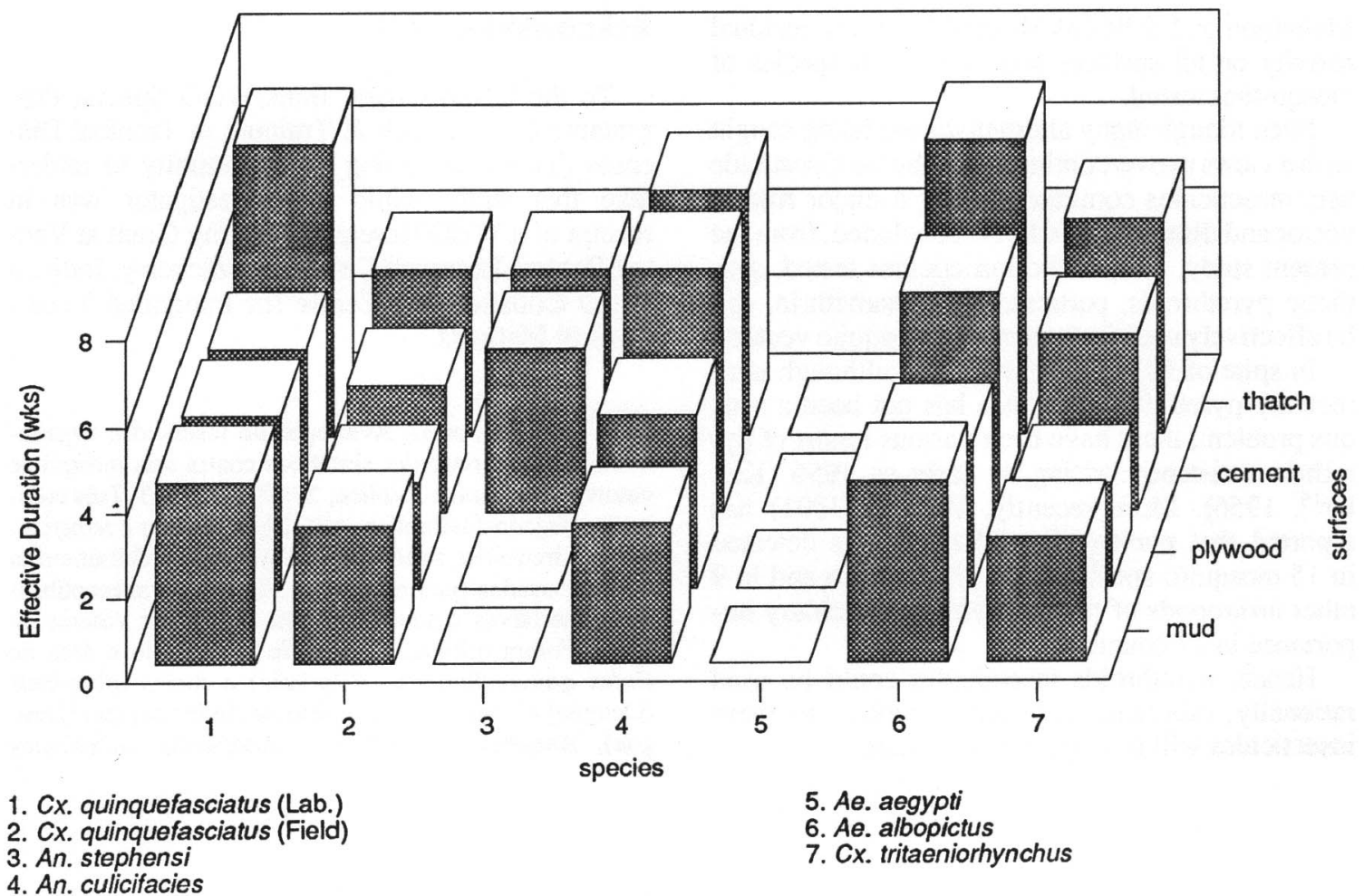

Figure 3. Residual efficacy of Malathion. 


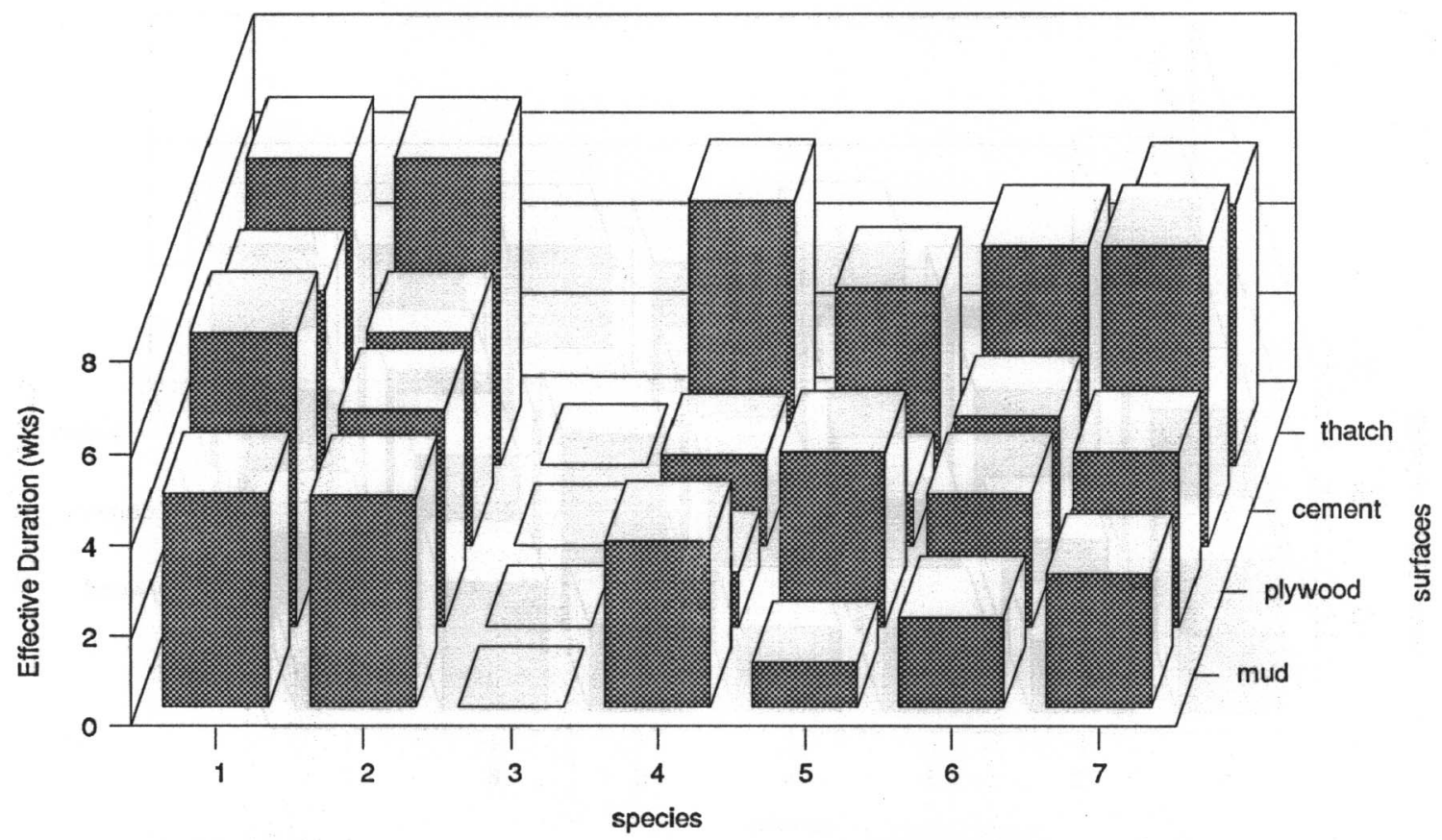

1. Cx. quinquefasciatus (Lab.)

2. Cx. quinquefasciatus (Field)

3. An. stephensi

4. An. culicifacies
5. Ae. aegypti

6. Ae. albopictus

7. Cx. tritaeniorhynchus

Figure 4. Residual efficacy of Folithion.

Malathion and folithion showed very low residual activity on all surfaces and against all species of mosquitoes tested.

Even though many altcrnatives are being sought with a views to overcoming the problem of pesticide use, insecticides continue playing a major role in vector and disease control. It is concluded, from the present study, that, of the insecticides tested, synthetic pyrethroids, particularly, alphamethrin, can be effectively used for controlling mosquito vectors.

In spite of above mentioned and although until recently pyrethroid resistance has not been a serious problem, there have been various report of pyrethrin resistance arising as early as 1956 (Keller $\left.{ }^{15}, 1956\right)$. More recently, WHO ${ }^{27}$ (1991) has reported that pyrethroids resistance was detected in 15 mosquito species from 32 countries and in 9 other arthropods of public health or veterinary im. portance in 27 countrics.

Hence, pyrethroids insecticides could be used rationally, otherwise resistance problem to these insecticides will be appear in the future.

\section{Acknowledgement}

To the UNDP/World Bank/WHO Special Programme for Research \& Training in Tropical Diseases (TDR) for giving an opportunity to undertake this study while the investigator was in receipt of a WHO Research Training Grant at Vector Control Research Centre, Pondicherry, India, a WHO Collaborating. Centre for Integrated Vector Control Methods.

DORTA, D.M. et al. Avaliação de inseticidas organofosforados e piretroides sintéticos contra seis mosquitos vetores. Rev. Saúde Pública, 27: 391-7, 1993. Três compostos organo-fosforados - malation, folition e temefos e dois piretroides sintéticos - alfametrina e deltametrina - foram usados para controlar o estado da susceptibilidade das larvas e adultos de seis mosquitos vetores na India. Foram utilizadas cepas de laboratório e área de Culex quinquefasciatus (filariasis) e Aedes albopictus (Dengue) e cepas de laboratório de Aedes aegypti (Dengue), Anopheles stephensi e Anopheles culicifacies 
(Malária) e Culex tritaenorhynchus (encefalite japonesa). Os valores de $\mathrm{Cl}_{50}$ obtidos para esses inseticidas mostram que todas as espécies incluindo as cepas de área foram muito susceptíveis. Nos mosquitos adultos das referidas espécies salvo na cepa da área de Culex quinquefasciatus com o malathion, observou-se $100 \%$ da mortalidade às doses discriminatórias recomendadas pela Organização Mundial de Saúde. $O$ efeito residual da alfametrina, deltametrina, malation e folition a $25 \mathrm{mg}$ (ai) $/ \mathrm{m}^{2}$ em diversas superfícies contra seis espécies de mosquitos vetores evidenciou que a alfametrina foi a mais efetiva em todas as superfícies ratadas (argila, "plywood", cimento e palha).

Descritores: Controle de mosquitos, métodos. Inseticidas, toxicidade. Insetos vetores.

\section{References}

1. ABBOTT, W.S. A method of computing the effectiveness of insecticides. J. Econ. Entomol., 18: 265-7, 1925.

2. ALMARAJ, D. et al. Evaluation of Alphamethrin a synthetic pyrethroid insecticidal activity aga' 1 st mosquitocs. Indian J, Med. Res., 86: 601-9, 1987.

3. ARIARATNAM, V. \& GEORGHIOI G.P. Carbamate resistance in Anopheles albimanus. penctration and metabolism of carbaryl in propoxur selected larvae. Bull. World Health Organ., 53: 91, 1975.

4. BEROZA, M. Chemical controlling insect behaviour. London, Academic Press, 1970.

5. BUSVINE, J.R. Development of the WHO resistance test for mosquitoes. Indian J. Malariol., 12: 279, 1958.

6. DARWAZEH, D.A. et al. Synthetic pyrethroids for the control of resistant mosquitoes in irrigated pastures. Proc. Pap. California Mosq. Cont. Assoc., 46: 121, 1978.

7. DAS, P.K. \& RAJAGOPALAN, P.K. Susceptibility of larvae of Culex fatigans (Wiedemann). Anopheles stephensi (Liston) and Aedes aegypti (Lin) to insecticides in Pondicherry. Indian J. Med. Res., 70: 412-6, 1979.

8. DAS, P.K. \& RAJAGOPALAN, P.K.Insecticides resistance in Culex pipiens fatigans and its relevance to vector control. Indian J. Med. Res., 72: 50, 1980.

9. DAS, P.K. et al. Insecticides susceptibility status of some mosquitoes in Pondicherry. Indian J. Med. Res., 72: 214-7, 1980.

10. DAS, P.K. \& KALYANASUNDARAM, M. Evaluation of K-otrire a synthetic pyrethroid for insecticidal efficacy against mosquito vectors. Indian J. Med. Res., 80: $74-7,1984$

11. ELLIOT, M. et al. The future of pyrethroids in insect control. Annu Rev. Entomol., 23: 443, 1978.

12. GEORGHIOU, G.P. et al. Carbamate resistance in mosquitoes: selection of Culex pippiens fatigans (Wiedemann)
(Cx. quinquefasciatus says) for resistance to Baygon. Bull. World Health Organ., 35: 691, 1966.

13. GEORGHIOU, G.P. Organophosphate multiresistance in Culex quinquefasciatus in Califomia. J. Econ. Ento. mol., 65: 461, 1973.

14. HASSALL, K.A. The chemistry of pesticides, London, Mac. Millan Press, 1982.

15. KELLER, J.C. et al. Susceptibility of insecticide-resistant cockroaches to pyrethrin. Pest Control, 24: 14-5, 1956.

16. KOTTKUMP, W.B. et al. Efficacy of three pyrethroids as larvicides against rice and mosquito larvae in field plots. Mosq. News, 41: 382, 1981.

17. MANSON-BAHR, P.E.C. \& BELL, D.R. Manson's tropical disease. 18.ed. London, Bailliere Tindall, 1982.

18. POIESTER, T.M. et al. Toxicity of pyrethroids to organophosphate-carbamate and DDT resistant mosquitoes. Masquito News, 41: 143, 1981.

19. RAJAVEL, A.R. et al. Evaluation of a synthetic pyrethroid (Cyfluthrin) for insecticidal activity against different mosquito species. Indian J. Med. Res., 5: 168$75,1987$.

20. ROBERT L.L. \& OLSON, J.K. Susceptibility of female Aedes albopictus from Texas to conmonly used adulticides. J. Amer. Mosq. Control Assoc., 5: 251-3, 1990.

21. SOKAL, R.R. \& ROHIF, J.P. Biometry: the principles and practice of statistics in biological research. 2nd ed. New York, W.H. Crreamn and Co. 1981. p. 180-445.

22. WESSON, D.M. Susceptibility to organophosphate insecticides in larval Aedes albopictus. J. Amer. Mosq. Control Assoc., 6: 258-64, 1990.

23. WORLD HEALTH ORGANIZATION. Instructions for determining the susceptibility or resistance of adult mosquitoes to organochlorine, organophosphate and carbamate insecticides: establishment of baseline. Gcneva, 1981. (WIIO mimeographed document VBC/ 81.805).

24. WORLD HEALTII ORGANTZATION. Instructions for determining the susceptibility or resistance of mosquito larvae to insecticides. Geneva, 1981. (WHO mimco. graphed document VBC/81.807).

25. WORLD HEALTH ORGANIZATION. Instructions for the bio-assay of insecticidal deposits on wall surfaces. Geneva, 1981. (WHO mimeographed document VBC/81.5).

26. WORLD. HEALTH ORGANIZATION EXPERT COMMITTEE ON VECTOR BIOLOGY AND CONTROL, Geneva, 1985. Resistance of vectors and reservois of disease to pesticides. Geneva, 1986 (WHO-Technical Report Series, 737)

27. WORLD HEALTH ORGANIZATION EXPERT COMMITTEE ON VECTOR BIOLOGY AND CONTROL, Geneva, 1991. Vector resistance to pesticides; report (WIIO-Technical Report Series, 818).

Recebido para publicaçāo em 24.11.1992 Reapresentado em 28.6.1993 Aprovado para publicação em 15.9 .1993 